\title{
Relationship between graphite flake sizes and the mechanical properties of grey iron
}

\author{
Adedayo, A. V. \\ Department of Materials Science and Engineering, Obafemi Awolowo University, Ile-Ife, Nigeria \\ Department of Metallurgical Engineering, Kwara State Polytechnic, PMB 1375, Ilorin, Nigeria
}

\section{Email address:}

adelekeadedayo58@yahoo.com, victor.adedayo@kwarapolytechnic.com(Adedayo,A.V.)

\section{To cite this article:}

Adedayo, A.V.. Relationship between Graphite Flake Sizes and the Mechanical Properties of Grey Iron. International Journal of Materials Science and Applications. Vol. 2, No. 3, 2013, pp. 94-98. doi:10.11648/j.ijmsa.20130203.14

\begin{abstract}
Cast Irons are important engineering materials which possess a wide range of attractive properties. Their properties are significantly dependent on the microstructure of the cast, cast iron components. A way of controlling the microstructure of cast iron is through the control of cooling rates during solidification. To control cooling rate, the heat storage capacity of the mould is important. This paper presents the report of a study on the characteristic effects of graphite flake sizes on some mechanical properties of grey cast iron. Six mould materials with heat storage capacities ranging from $1.52 \mathrm{~kJ} \cdot \mathrm{m}^{-2} \cdot \mathrm{K}^{-1} \cdot \mathrm{s}^{-1 / 2}$ to $2.16 \mathrm{~kJ} \cdot \mathrm{m}^{-2} \cdot \mathrm{K}^{-1} \cdot \mathrm{s}^{-1 / 2}$ were prepared and used to cast some grey cast iron samples whose microstructures were observed by optical microscopy. Mechanical properties of the grey iron were evaluated. The results show that the properties increased with the heat storage capacity of the mould. Also, the microstructures show a dependence on heat storage capacity of the mould.
\end{abstract}

Keywords: Graphite, Graphitization, Cementite, Grey Iron

\section{Introduction}

Grey Irons (G.I.) is characterized by presence of a large portion of its carbon in the form of graphite flakes. Although G.I. is often defined as steel containing graphite, its properties are far different from those of steels (Rajput, 2006). The reasons for these differences may follow from the structural differences between G.I. and steel microstructures. Generally, the chemical composition of a material has much influence on the properties of the material (Adedayo and Ibitoye, 2010; Adedayo and Oyetoyan, 2010; Adedayo et al., 2010; Adedayo 2009a; Adedayo, 2009b), however even materials of the same composition may have great difference in their properties due to differences in their structural make up.

Both the microstructure and the macrostructure have great influence on the properties of a material (Adedayo, 2010;Adedayo et al., 2010; Imaev et al., 2006; Yu et al., 2004). For example, steel weld metal microstructure is a complex mixture of two or more constituents, such as proeutectoid ferrite, polygonal ferrite, aligned and non-aligned side plate ferrite, ferrite carbide aggregates and acicular ferrite (Adedayo et al., 2010). Sometimes, upper and lower bainites, martensites and the A-M (austenite with martensite) microconstituents may be formed (Adedayo et al., 2010). This complex microstructure mixture can lead to highly varied properties of the weld. Generally, the properties of a material are related to its structural make-up (Adedayo et al., 2010; Adedayo, 2009a). A way to control the structure of the materials is by control of cooling and solidification rates (Adedayo, 2010). The basic structures of G.I. can be altered by cooling and solidification rates during casting.

In this present study, exposition on the relationship between graphite flake sizes and the mechanical properties of G.I. is made. The role of the Heat Storage Capacity (HSC) on the graphite flake sizes is also elucidated.

\section{Experimental Procedure}

G.I. with different flake sizes was produced by sand casting using moulding sand of different heat storage capacities. To prepare moulding sand with different heat storage capacities, new silica sand was obtained and mixed with bentonite, coal dust and water. To every $25 \mathrm{~kg}$ of silica sand was added $2.25 \mathrm{~kg}$ of bentonite, $1.5 \mathrm{~kg}$ of coal dust, 1.75 litres of water. The sand constituents were mixed using Ridsdale continuous muller. 
With this composition of silica sand, other five different compositions of silica sand were prepared by addition of varying percentages of iron filings to the silica sand. This serves to vary the Heat Storage Capacity (HSC) of the mould material. The HSC is expressed as the root of the product of the thermal conductivity, the specific heat capacity and the density of the mould materials. i.e:

$$
H S C=\sqrt{\lambda . c . \rho}
$$

where $\lambda$ is the thermal conductivity, $\mathrm{c}$ the specific heat capacity and $\rho$ the density of the mould materials. For a mould made of different materials, a simple proportion formula was used to evaluate the resultant HSC i.e.

$$
H S C_{\text {multicomponet }}=\Sigma f_{i} \sqrt{\lambda_{i} \cdot c_{i} \cdot \rho_{i}}
$$

where $f_{i}$ is the fraction of component $\mathrm{i}$ in a multi-component mould (see tables 1 and 2). A control sample, which had no Fe content, was also prepared (see table 3).

Table 1. Standard composition of the green moulding sand

\begin{tabular}{ll}
\hline Materials & Weight composition (wt \%) \\
\hline Silica sand & 82 \\
Bentonite & 7 \\
Coal dust & 5 \\
Water & 6 \\
\hline
\end{tabular}

Table 2. Physical properties of the mould materials

\begin{tabular}{llll}
\hline Materials & $\begin{array}{l}\text { Thermal } \\
\text { conductivity } \\
\left(\mathrm{W}^{-1} \cdot \mathrm{K}^{-1}\right)\end{array}$ & $\begin{array}{l}\text { Specific } \\
\text { capacity } \\
\left(\mathrm{kJ}^{-1} \mathrm{~kg}^{-1} \cdot \mathrm{K}^{-1}\right)\end{array}$ & $\begin{array}{l}\text { hensity } \\
\left(\mathrm{kg} \cdot \mathrm{m}^{-3}\right)\end{array}$ \\
\hline Silica sand & 0.657 & 2.01 & 1700 \\
Bentonite & 1.035 & 1.089 & 1850 \\
Coal dust & 0.186 & 1.31 & 1200 \\
Water & 0.551 & 4.212 & 999.9 \\
Iron & 63 & 0.502 & 7220 \\
\hline
\end{tabular}

Table 3. Specimen with percentages and masses of Fe filings contents

\begin{tabular}{lllll}
\hline \multirow{2}{*}{$\begin{array}{l}\text { Mold } \\
\text { material }\end{array}$} & \multicolumn{2}{l}{ Percentage of } & Mass of Fe & \multicolumn{2}{l}{ Heat storage capacity of } \\
& Fe filings & $\begin{array}{l}\text { Mould, HSC, } \\
\text { filings }(\mathrm{kg})\end{array}$ & $\begin{array}{l}\text { the } \\
\left(\mathrm{kJ} \cdot \mathrm{m}^{-2} \cdot \mathrm{K}^{-1} \cdot \mathrm{s}^{-1 / 2}\right)\end{array}$ \\
\hline A & - & - & 1.52 \\
A1 & 1 & 0.3 & 1.65 \\
A2 & 2 & 0.6 & 1.77 \\
A3 & 3 & 0.9 & 1.90 \\
A4 & 4 & 1.2 & 2.03 \\
A5 & 5 & 1.5 & 2.16 \\
\hline
\end{tabular}

These sand samples were used to prepare moulds of about $60 \mathrm{~kg}$ (both the cope and the drag) and used to cast samples of grey C.I. rods ( $25 \mathrm{~mm}$ diameter and $500 \mathrm{~mm}$ in length).

Tensile, impact and hardness test pieces were produced from the cast rods through machining on the lathe machine. The tensile and impact test specimen were machined to ASTM E8M-88 standard test samples (see Fig.1). During machining, coolants were continuously used to control the temperature of the specimen. The cutting speed was also extremely low. These were to guide against any over heating which may lead to change in microstructure of the samples. The produced samples were then tested for tensile strength, toughness and hardness. Metallographic samples were also prepared by a gentle grinding on abrasive silicon carbide papers of successive finer grades 240, 320, 400 and 600 lubricated with water. Polishing of the specimens was carried out on a $150 \mathrm{~mm}$ rotating disc of a METASERV universal polisher. $7 \mu$ and $15 \mu$ diamond pastes were used, while kerosene was used as the solvent. Having obtained mirror like surface, the polished samples were etched using $2 \%$ Nital. The etched specimens were observed on the Olympus metallurgical microscope with a minisee optical viewing system connected to the USB port of a computer in the department of materials science and engineering of the Obafemi Awolowo University. Micro examination was carried out at a magnification of x100 and images captured for metallographic analysis. The graphite flakes in the microstructure was characterized as inspired by AFS and ASTM graphite flake type and size rating charts.
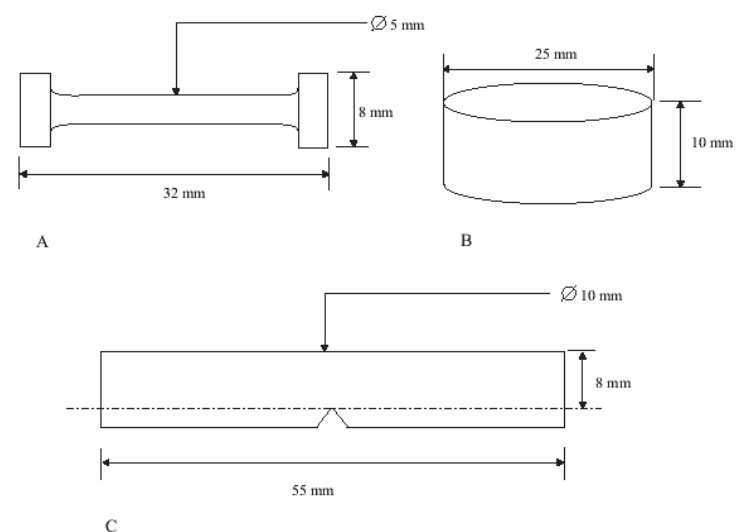

Fig 1. Dimensions of ASTM E8M-88 standard test pieces used: (A) tensile test piece, (B) Hardness and metallographic samples, (C) Impact test piece

\section{Results and Discussion}

Tables 4, 5, 6 and 7 present the raw data obtained from property tests carried out on the prepared G.I. These tables were used to generate the figures (i.e. Figures 2 to 5). Table 8 presents the variation of length of graphite flake with HSC. This was used to generate Figure 6. In general, the evaluated material properties increased with the HSC, however, they decreased with the graphite flake sizes.Tensile strength ranged from $2.14 \times 10^{8} \mathrm{~N} . \mathrm{m}^{-2}$ to $2.73 \times 10^{8} \mathrm{~N} . \mathrm{m}^{-2}$, elongation from $13 \%$ to $18 \%$ and Hardness values ranged from 168 $\mathrm{BHN}$ to $194 \mathrm{BHN}$. The toughness values are between $17.7 \mathrm{~J}$ and 20.6 J. However, the microstructures of the prepared G.I. (Figures 7 A, A1, A2, A3, A4, and A5) reveal that length of the graphite flakes decreased with HSC. It decreased from $0.1 \mathrm{~m}$ at $1.52 \mathrm{~kJ} \cdot \mathrm{m}^{-2} \cdot \mathrm{K}^{-1} \cdot \mathrm{s}^{-1 / 2} \mathrm{HSC}$, to about $0.003125 \mathrm{~m}$ at $2.16 \mathrm{~kJ} \cdot \mathrm{m}^{-2} \cdot \mathrm{K}^{-1} \cdot \mathrm{s}^{-1 / 2} \mathrm{HSC}$. 
Table 4. Variation of tensile strength with graphite flake sizes

\begin{tabular}{|c|c|c|c|}
\hline $\begin{array}{l}\text { Mould } \\
\text { material }\end{array}$ & $\begin{array}{l}\text { Heat storage capacity of } \\
\text { the mould, HSC, } \\
\left(\mathrm{kJ} \cdot \mathrm{m}^{-2} \cdot \mathrm{K}^{-1} \cdot \mathrm{s}^{-1 / 2}\right)\end{array}$ & $\begin{array}{l}\text { Average } \\
\text { graphite flake } \\
\text { sizes }\end{array}$ & $\begin{array}{l}\text { Average } \\
\text { tensile } \\
\text { strength } \\
\left(\mathrm{N} . \mathrm{m}^{-2}\right)\end{array}$ \\
\hline A & 1.52 & 0.075 & $2.14 \times 10^{8}$ \\
\hline A1 & 1.65 & 0.0375 & $2.18 \times 10^{8}$ \\
\hline $\mathrm{A} 2$ & 1.77 & 0.0375 & $2.24 \times 10^{8}$ \\
\hline A3 & 1.90 & 0.01875 & $2.31 \times 10^{8}$ \\
\hline A4 & 2.03 & 0.009375 & $2.44 \times 10^{8}$ \\
\hline A5 & 2.16 & 0.0046875 & $2.73 \times 10^{8}$ \\
\hline
\end{tabular}

Table 5. Variation of hardness number with graphite flake sizes

\begin{tabular}{llll}
\hline $\begin{array}{l}\text { Mould } \\
\text { material }\end{array}$ & $\begin{array}{l}\text { Heat storage capacity of } \\
\text { the mould, HSC, } \\
(\mathrm{kJ} . \mathrm{m}-2 . \mathrm{K}-1 . \mathrm{s}-1 / 2)\end{array}$ & $\begin{array}{l}\text { Average } \\
\text { graphite flake } \\
\text { sizes }\end{array}$ & $\begin{array}{l}\text { Average } \\
\text { hardness } \\
\text { number } \\
(\mathrm{BHN})\end{array}$ \\
\hline $\mathrm{A}$ & 1.52 & 0.075 & 168 \\
$\mathrm{~A} 1$ & 1.65 & 0.0375 & 172 \\
$\mathrm{~A} 2$ & 1.77 & 0.0375 & 175 \\
$\mathrm{~A} 3$ & 1.90 & 0.01875 & 182 \\
$\mathrm{~A} 4$ & 2.03 & 0.009375 & 186 \\
$\mathrm{~A} 5$ & 2.16 & 0.0046875 & 194 \\
\hline
\end{tabular}

Table 6. Variation of elongation with graphite flake sizes

\begin{tabular}{llll}
\hline $\begin{array}{l}\text { Mould } \\
\text { material }\end{array}$ & $\begin{array}{l}\text { Heat storage capacity of } \\
\text { the } \\
\text { mould, }\end{array}$ & $\begin{array}{l}\text { Average } \\
\text { graphite } \\
\text { flake sizes }\end{array}$ & $\begin{array}{l}\text { Average } \\
\text { elongation } \\
(\%)\end{array}$ \\
\hline A & 1.52 & 0.075 & 13 \\
A1 & 1.65 & 0.0375 & 13 \\
A2 & 1.77 & 0.0375 & 13.5 \\
A3 & 1.90 & 0.01875 & 14 \\
A4 & 2.03 & 0.009375 & 15 \\
A5 & 2.16 & 0.0046875 & 18 \\
\hline
\end{tabular}

Table 7: Variation of toughness with graphite flake sizes

\begin{tabular}{llll}
\hline $\begin{array}{l}\text { Mould } \\
\text { material }\end{array}$ & $\begin{array}{l}\text { Heat storage capacity of } \\
\text { the } \\
\text { mould, }\end{array}$ & $\begin{array}{l}\text { Average } \\
\text { graphite } \\
\text { flake sizes }\end{array}$ & $\begin{array}{l}\text { Average } \\
\text { toughness }(\mathrm{J})\end{array}$ \\
\hline A & 1.52 & 0.075 & 17.7 \\
A1 & 1.65 & 0.0375 & 18 \\
A2 & 1.77 & 0.0375 & 18.3 \\
A3 & 1.90 & 0.01875 & 18.6 \\
A4 & 2.03 & 0.009375 & 20.3 \\
A5 & 2.16 & 0.0046875 & 20.6 \\
\hline
\end{tabular}

Table 8. Variation of length of graphite flake with HSC

\begin{tabular}{llll}
\hline $\begin{array}{l}\text { Mould } \\
\text { material }\end{array}$ & $\begin{array}{l}\text { Heat storage capacity } \\
\text { of the mould, HSC, } \\
\left(\mathrm{kJ} \cdot \mathrm{m}^{-2} \cdot \mathrm{K}^{-1} \cdot \mathrm{s}^{-1 / 2}\right)\end{array}$ & $\begin{array}{l}\text { Length of } \\
\text { graphite } \\
\text { flakes }(\mathrm{m})\end{array}$ & $\begin{array}{l}\text { Average } \\
\text { graphite flake } \\
\text { sizes }\end{array}$ \\
\hline A & 1.52 & 0.05 to 0.1 & 0.075 \\
A1 & 1.65 & 0.025 to 0.05 & 0.0375 \\
A2 & 1.77 & 0.025 to 0.05 & 0.0375 \\
A3 & 1.90 & 0.0125 to & 0.01875 \\
& & 0.025 & 0.00625 to \\
A4 & 2.03 & 0.0125 & 0.009375 \\
& & 0.003125 to & 0.0046875 \\
A5 & 2.16 & 0.00625 & \\
\hline
\end{tabular}

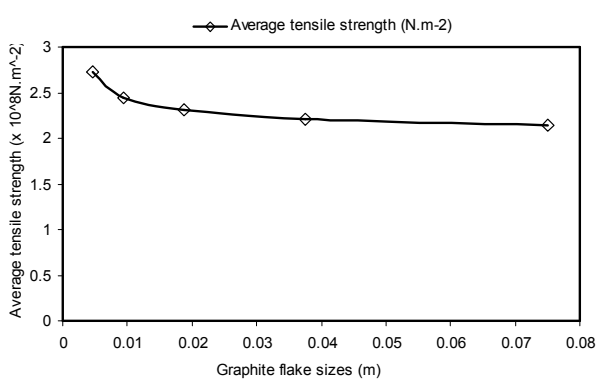

Figure 2. Variation of tensile strength with graphite flake sizes

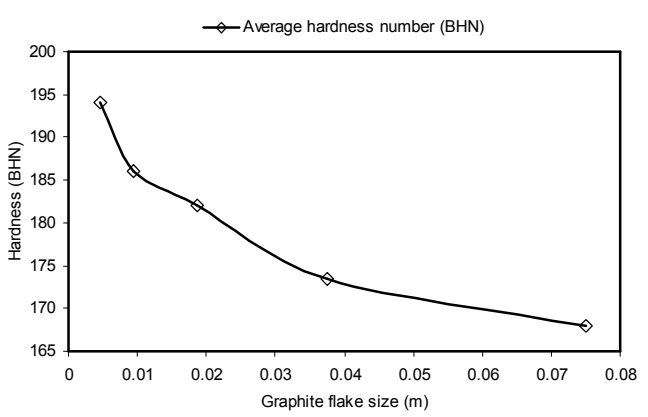

Figure 3. Variation of hardness number with graphite flake sizes

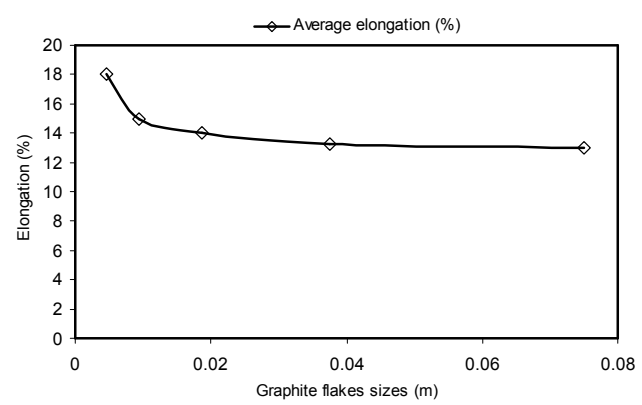

Figure 4. Variation of elongation with graphite flake sizes

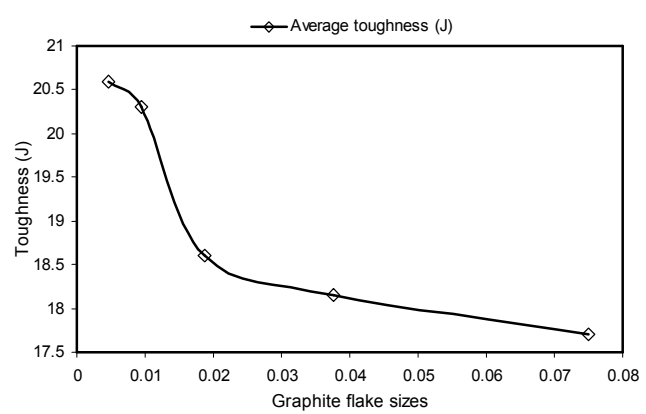

Figure 5. Variation of toughness with graphite flake sizes

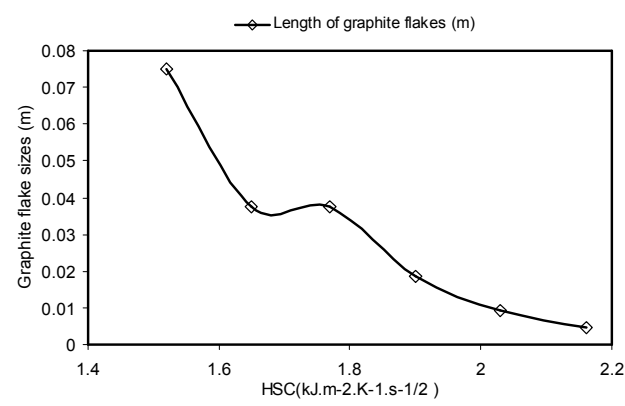

Figure 6. Variation of graphite flakes length with HSC 


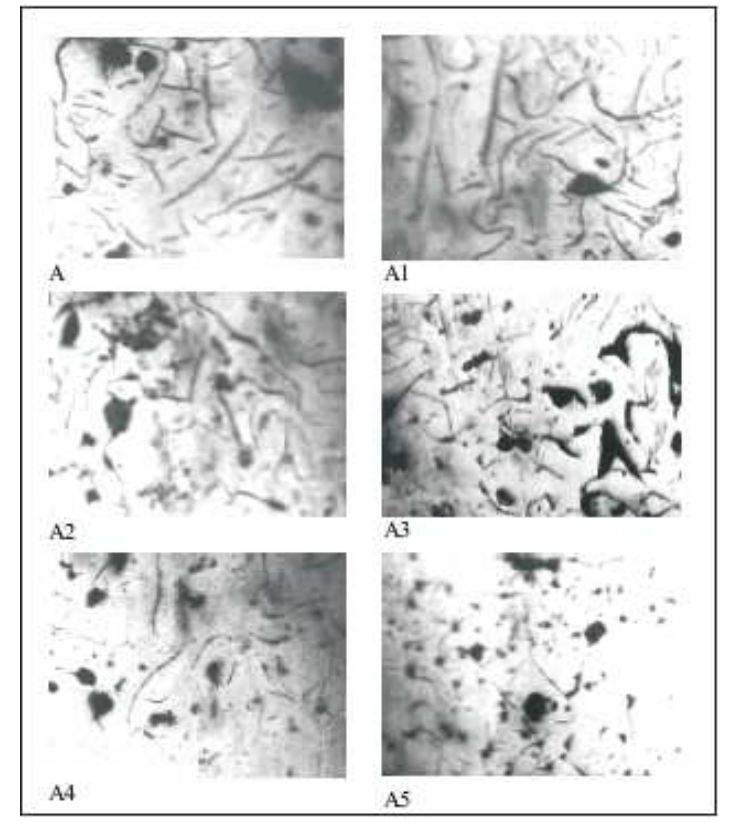

Figure 7. Microstructures (x100) of G.I. cast by mould material A, A1, A2, $A 3, A 4$, and $A 5$ respectively

Generally, during solidification of G.I., primary austenite $(\gamma)$ will separate out first until the eutectic temperature is reached. At eutectic temperature, eutectic consisting of austenite and graphite would form (Adedayo, 2010; Higgins, 2004). This is due to the presence of sufficient silicon which increases the instability of cementite. The eutectic develops from nuclei and is in the form of approximately spherical particles known as eutectic cells. Graphite appears to be in the form of separate flakes, but in fact the eutectic cells are three dimensional and roughly spherical in shape (Higgins, 2004). Rapid cooling, which produces a greater degree of under cooling initiates the formation of a greater number of eutectic cells and also more frequent branching in the eutectic graphite "leaves", giving much finer graphite flakes. The smaller the eutectic cells, the finer the graphite flakes. This explains the observed trend in gradual change from coarse to fine graphite flakes in the microstructure. Also, if subsequent cooling proceed slowly enough, at the eutectoid transformation, instead of forming cementite $\left(\mathrm{Fe}_{3} \mathrm{C}\right)$, the carbon diffuses to the nearest graphite flake and precipitates there as additional graphite (Flemings, 1974). The rejection of carbon in the austenite phase is a process controlled by diffusion, which in turn, is temperature dependent.

During graphitization, free carbon is precipitated in the iron or chemically combined carbon $\left(\mathrm{Fe}_{3} \mathrm{C}\right)$ is changed to free carbon (or graphite), thus leading to a reduction in quantity of cementite present in the G.I. microstructure. Actually, fine dispersion of iron carbide $\left(\mathrm{Fe}_{3} \mathrm{C}\right)$ can be responsible for straining ferrite matrix in G.I. which can lead to increased hardness and strength. Strengthening of bainitic structures has been reported to be due to straining of ferrite matrix by iron carbide (Brophy et al, 1964). Generally, a fast cooling rate promotes formation of cementite. This is due to suppression of the graphitization process. A slower cooling rate allows sufficient time for graphitization. This, most often lead to a mixed microstructure consisting of cementite and graphite (Moffatt et al, 1964). A higher HSC value suppresses this carbon rejection process through rapid cooling. The iron content of the mould induced this change in HSC of the mould.

Further more, the three dimensional graphite flakes that formed during eutectic reaction, dispersed in a matrix of ferrite, pearlite or other iron-based structures have no appreciable strength, they act essentially as voids in the structure. The pointed edges of the flakes act as preexisting notches or cracks initiation site (DeGarmo et al, 2003; DeGarmo et al, 1999), thus giving the material a reduced strength. Fracture mechanics have identified a relationship between crack size and material properties (Callister , 1985). In general, higher values of crack length lead to a reduced material strength.

\section{Conclusion}

The research shows that the HSC of the mould has significant effects on the graphite flakes sizes in the microstructure of G.I. Graphite flakes sizes in turn affects the properties of G.I. This suggests that HSC of a mould could be varied as required to effect changes in the microstructure, tensile strength, elongation, hardness and toughness of G.I.

\section{Acknowledgements}

Nigerian Machine Tools Limited, Osogbo, Osun State, Nigeria is acknowledged for assistance in mould preparation, melting and casting of the grey cast iron samples.

\section{References}

[1] Adedayo A.V. 2010 Effects of addition of iron filings to green moulding sand on the microstructure of grey cast iron. Journal of the Brazilian Society for Mechanical Sciences and Engineering, Vol. XXXII, No 2, pp 171-175

[2] Adedayo A.V. 2009a Effects of carbon content on steel welds. Journal of Research in Technology and Engineering Management, Vol. 2, No. 1 pp131-135

[3] Adedayo, A.V 2009b Effects of Iron Filings on the Properties of Green Moulding Sand, Proceedings of $2^{\text {nd }}$ National Conference of Institute of Technology, Kwara State Polytechnic, Ilorin, Vol 2, No 1, pp45-49

[4] Adedayo A.V.,and Ibitoye, S.A.(2010) Effects of carbon and oxyfuel pressures on kinetics of OFC-A of steels, Pacific Journal of Science and Technology (PJST), vol. 11, no 2 pp 9-15

[5] Adedayo A.V., Ibitoye, S.A., and Oyetoyan, O.A. 2010 Annealing heat treatment effects on steel welds. Journal of Mineral, Materials Characterization and Engineering, Vol. 9, No. 6 pp 601-611.

[6] Adedayo, A.V and Oyetoyan, O.A. (2010) Formulation for 
predicting cutting rates of OFC-A of steels, Proceedings of 3rd National Conference of Institute of Technology, Kwara State Polytechnic, Ilorin, Vol 3, No 1, pp 57-60

[7] Brophy, J.H., Rose, R.M.; Wulff J., 1964 The structure and properties of materials, thermodynamics, vol.2, John Wiley and Sons, Brisbane, pp 113-114, 188-189

[8] Callister W.J. 1985 Materials science and engineering, an introduction. John Wiley \& Sons, NY, pp 717 -731

[9] DeGarmo E.P., Black J.T., Kosher R.A.(2003 Material and processes in manufacturing $9^{\text {th }}$ ed. John Wiley and Sons, New York, pp 60-100, 375 - 408, 1100-1123

[10] DeGarmo E.P., Black J.T., Kosher R.A. 1999 Material and processes in manufacturing $8^{\text {th }}$ ed. John Wiley and Sons, New York, pp 90-93,345-415, 1114

[11] Flemings M.C. 1974 Solidification processing; Materials science and engineering series. McGraw-Hill New York. pp 184
[12] Heine R.W., Loper C.R., Rosenthal P.C. 2003 Principles of metal castings, $26^{\text {th }}$ reprint, TMH ed. New York, pp 86.

[13] Higgins, R.A. 2004 Engineering metallurgy: Applied physical metallurgy. $6^{\text {th }}$ ed. Viva books, New Delhi, pp 355, 356

[14] Imaev R.M., Imaev V.M., Khismatullin T.G. 2006Refinning of the microstructure of cast intermetallic alloy Ti-43\% Al-X $(\mathrm{Nb}, \mathrm{Mo}, \mathrm{B})$ with the help of heat treatment, Metallovedenie I Termicheskaya Obrabotka Metallov, No.2, pp 38-41

[15] Moffatt, W.G.; Pearsall, G.W.; Wulff, J. 1964 The structure and properties of materials, structure, vol.1, John Wiley and Sons, Brisbane, pp 134, 195

[16] Rajan T.V., Sharma C.P., Sharma A. 1988 Heat treatment principles and techniques, Prentice-Hall of India, Private Ltd, New Delhi, pp11-14, 289, 331.

[17] Rajput R.K. 2006 Engineering materials and metallurgy, $1^{\text {st }}$ ed. S. Chand \& Co. New Delhi., pp 13, 28-31, 101 